\title{
Konstruksi Hukum \\ Perlindungan Korban Kekerasan Berbasis Gender Online Menurut Hukum Hak Asasi Manusia
}

\author{
Fadillah Adkiras \\ Magister Hukum Fakultas Hukum Universitas Islam Indonesia Yogyakarta Indonesia \\ Jln. Cik Di Tiro No. 1 Yogyakarta Indonesia \\ dilladkiras@gmail.com
}

\begin{abstract}
This study aims to determine the legal protection for victims of online gender-based violence in Indonesia and the legal construction of protection for victims of online gender-based violence according to human rights law. This is a normative legal research that uses statutory, case, and conceptual approaches. The results of this study are first, Indonesia does not have legislation that specifically regulates legal protection for victims of Online Gender Based Violence (KBGO) so that the handling of cases KBGO-related is still based on Law Number 11 of 2008 on Information and Electronic Transactions (ITE Law) and Law Number 44 of 2008 on Pornography (Pornography Law). However, the two laws have not comprehensively regulated the protection of KBGO victims. Second, the legal construction of protection for KBGO victims has generally been regulated in the Bill of Elimination of Sexual Violence (PKS Bill). However, to fulfill the protection of KBGO victims, the PKS Bill needs to be revised by regulating provisions regarding the expansion of the definition of 'indirectly', recovery of victim digital data, the process of establishing cooperation between UPT and the National Cyber and Crypto Agency (BSSN), online reporting, mechanisms for handling and social protection of victims, special procedures related to the procedural law, and improving the legal structure (law enforcement officers).
\end{abstract}

Key Words: Human rights; legal protection; online gender-based violence

\begin{abstract}
Abstrak
Penelitian ini bertujuan untuk mengetahui perlindungan hukum korban kekerasan berbasis gender online di Indonesia dan konstruksi hukum perlindungan korban kekerasan berbasis gender online menurut hukum hak asasi manusia. Penelitian ini merupakan penelitian hukum normatif yang menggunakan pendekatan perundang-undangan, pendekatan kasus, dan pendekatan konseptual. Hasil penelitian ini menyimpulkan pertama, bahwa Indonesia belum memiliki peraturan perundangundangan yang secara khusus mengatur perlindungan hukum korban Kekerasan Berbasis Gender Online (KBGO) sehingga penanganan kasus terkait KBGO masih berdasar pada Undang-Undang Nomor 11 Tahun 2008 tentang Informasi dan Transaksi Elektronik (UU ITE) dan Undang-Undang Nomor 44 Tahun 2008 tentang Pornografi (UU Pornografi). Akan tetapi, kedua undang-undang tersebut belum mengatur perlindungan korban KBGO secara komprehensif. Kedua, konstruksi hukum perlindungan korban KBGO secara umum diatur dalam Rancangan Undang-Undang Penghapusan Kekerasan Seksual (RUU PKS). Akan tetapi, untuk memenuhi perlindungan korban KBGO, RUU PKS tersebut perlu direvisi dengan mengatur ketentuan mengenai perluasan definisi 'secara tidak langsung', pemulihan data digital korban, proses penjalinan kerjasama antara UPT dengan Badan Siber dan Sandi Negara (BSSN), pelaporan online, mekanisme penanganan dan perlindungan korban secara sosial, prosedur khusus terkait hukum acaranya, dan memperbaiki struktur hukum (aparat penegak hukum).
\end{abstract}

Kata-kata Kunci: Hak asasi manusia; kekerasan berbasis gender online; perlindungan hukum 


\section{Pendahuluan}

Sebuah adagium ubi societas ibi ius yang berarti bahwa dimana ada masyarakat di situ ada hukum memberikan gambaran bahwa hukum tercipta pada saat manusia tercipta, karena pada saat ada manusia dan pergaulannya, pada saat itu pula hukum sudah ada. ${ }^{1}$ Namun, idealita untuk selalu menyelaraskan perkembangan hukum dengan perkembangan manusia nyatanya belum dapat optimal dikarenakan perkembangan masyarakat saat ini yang cenderung dinamis. Perkembangan masyarakat yang sangat cepat salah satunya disebabkan oleh perkembangan teknologi informasi. Pengertian teknologi informasi menurut Pasal 1 angka 3 Undang-Undang Nomor 11 Tahun 2008 tentang Informasi dan Transaksi Elektronik (UU ITE) adalah suatu teknik untuk mengumpulkan, menyiapkan, menyimpan, memproses, mengumumkan, menganalisis, dan/atau menyebarkan informasi.

Salah satu produk teknologi informasi yang memiliki peranan penting dan berhasil memacu perubahan tatanan masyarakat adalah internet. Internet tersebut tidak hanya memacu aspek-aspek yang berdampak positif, namun juga dapat menimbulkan dampak negatif, salah satunya adalah kejahatan yang ada di ranah internet (cyber crime). Budi Raharjo mendefinisikan cyber crime sebagai perbuatan yang melanggar hukum dengan memanfaatkan teknologi komputer yang memanfaatkan teknologi internet. ${ }^{2}$ Munculnya kasus-kasus yang berkaitan dengan cyber crime dapat menjadi ancaman bagi masyarakat karena masih banyak kasus terkait cyber crime yang salah satunya adalah kekerasan berbasis gender diranah cyber.

Kekerasan Berbasis Gender Online (KBGO) adalah bentuk turunan dari Kekerasan Berbasis Gender (KBG) yang oleh Committee on the Elimination of Discrimination against Women (CEDAW) didefinisikan sebagai kekerasan yang ditujukan kepada seorang perempuan karena dia perempuan atau kekerasan yang mempengaruhi seorang perempuan secara tidak proporsional, yang termasuk kerusakan atau penderitaan fisik, mental atau seksual, tindakan intimidasi, pemaksaan dan perampasan kebebasan. ${ }^{3}$ Terdapat hal penting yang perlu dicatat dalam definisi tersebut, yaitu bahwa KBG adalah tindakan kekerasan yang berlandaskan pada asumsi gender dan atau seksual tertentu, jika motif atau niatannya sama sekali tidak berkaitan dengan gender dan seksual,

${ }^{1}$ Peter Mahmud Marzuki, Pengantar Ilmu Hukum (Edisi Revisi), Kencana Prenanda Media Group, Jakarta, 2013, hlm. 41.

2 Budi Rahardjo, Memahami Teknologi Informasi, Elexmedia Komputindo, Jakarta, 2002, hlm. 92.

3CEDAW (1992), “General Recommendation No. 19” (11th session, 1992), Artikel: http://www.un.org/womenwatch/daw/cedaw/recommendations/index.html diakses pada 20 Juli 2020 Pada Pukul 19.49 WIB 
maka hal tersebut dikategorikan sebagai kekerasan umum. Sehingga dapat dikerucutkan bahwa KBGO merupakan bentuk KBG yang difasilitasi teknologi digital atau medium internet.

Komisi Nasional Anti Kekerasan terhadap Perempuan (Komnas Perempuan) melalui Catatan Tahunan (Catahu) 2020 menyatakan bahwa terdapat kenaikan yang cukup signifikan atas pengaduan kasus cyber crime berbasis gender, yaitu sejumlah 281 kasus yang secara presentase, naik sejumlah 300\% dari tahun sebelumnya yang tercatat sejumlah 97 kasus. ${ }^{4}$ KBGO ibarat sebuah fenomena gunung es, karena pelaporan kepada komnas perempuan saat ini sejatinya hanya sebagian kecil dari realita kasus yang ada.

Penyelesaian kasus-kasus terkait KBGO masih sangat rendah karena minimnya instrumen hukum yang bisa digunakan. Artinya, hanya beberapa kasus terkait KBGO yang dapat selesai hingga tahap pengadilan. Salah satunya adalah revenge porn yang dalam Bahasa Indonesia dikenal dengan istilah pornografi balas dendam yang merupakan suatu bentuk pornografi yang memanfaatkan kepemilikan materi pornografi yang awalnya diperoleh secara 'sah' namun kemudian disebarluaskan tanpa konsensus dengan tujuan balas dendam setelah putus dari sebuah hubungan. ${ }^{5}$ Penyelesaian kasus revenge porn saat ini terbatas dengan penggunaan UU ITE dan Undang-Undang Nomor 44 Tahun 2008 tentang Pornografi, dimana kedua peraturan tersebut masih berfokus kepada pemberian sanksi dan hukuman kepada pelaku yang juga malah melupakan konsep perlindungan terhadap korban. Association for Progressive Communications (APC) secara lebih lanjut mengklasifikasikan bentuk-bentuk KBGO menjadi beberapa kategori, yaitu pelanggaran privasi, pengawasan dan pemantauan (stalking), perusakan reputasi/kredibilitas, pelecehan, ancaman dan kekerasan langsung, dan serangan yang ditargetkan ke komunitas tertentu. ${ }^{6}$ Bentuk-bentuk KBGO tersebut akan terus mengalami pembaharuan seiring dengan perkembangan internet.

Pemaparan di atas menunjukkan urgensi adanya suatu bentuk desain konstruksi hukum atas perlindungan korban KBGO di Indonesia sebagaimana Pasal 28D ayat (1) Undang-Undang Dasar Negara Republik Indonesia Tahun 1945 (UUD 1945) yang menyatakan bahwa setiap orang berhak atas pengakuan, jaminan, perlindungan, dan kepastian hukum yang adil serta perlakuan yang sama dihadapan hukum. Negara selaku pemangku kewajiban berperan untuk menghormati (obligation to respect), melindungi (obligation to protect) serta

\footnotetext{
${ }^{4}$ Catatan Tahunan Komnas Perempuan 2020

5 Shigenori Matsuri, "The Criminalization of Revenge Porn in Japan”, Washington International Law Journal Association, Vol. 24 No. 2 2015, hlm. 289.

${ }^{6}$ Ibid., hlm. 4-6.
} 
memenuhi (obligation to fulfill) hak warga negaranya. ${ }^{7}$ Pemerintah dapat melakukan langkah-langkah efektif dan konkrit atas berbagai kebijakan hak asasi manusia dari segi hukum, politik, ekonomi, sosial, budaya pertahanan serta keamanan. Perlindungan dan jaminan atas hak asasi manusia tersebut pula harus didukung dengan aparatur negara baik dengan cara reformasi hukum yang lebih progresif guna mengisi kekosongan-kekosongan hukum dalam masyarakat yang dinamis. Oleh karena itu, penelitian ini akan mengkaji secara komprehensif terkait konstruksi hukum perlindungan korban kekerasan berbasis gender online menurut hak asasi manusia sebagai upaya memajukan pemenuhan terhadap hak asasi manusia yang ada di Indonesia.

\section{Rumusan Masalah}

Berdasarkan uraian latar belakang diatas, permasalahan hukum yang menjadi fokus kajian dalam penelitian ini adalah, pertama, bagaimanakah ketentuan peraturan perundang-undangan tentang jaminan perlindungan korban kekerasan berbasis gender online di Indonesia? kedua, Bagaimanakah konstruksi hukum perlindungan korban kekerasan berbasis gender online menurut hukum hak asasi manusia?

\section{Tujuan Penelitian}

Penelitian ini bertujuan untuk mengetahui ketentuan peraturan perundangundangan tentang perlindungan hukum korban kekerasan berbasis gender online di Indonesia dan konstruksi hukum perlindungan korban kekerasan berbasis gender online menurut hukum hak asasi manusia.

\section{Metode penelitian}

Penelitian ini merupakan penelitian hukum normatif yaitu penelitian hukum yang dilakukan dengan cara meneliti bahan pustaka atau bahan hukum. Pendekatan penelitian yang digunakan adalah pendekatan perundang-undangan, pendekatan kasus, dan pendekatan konseptual. Data penelitian terdiri atas bahan hukum primer, bahan hukum sekunder, dan bahan hukum sekunder, yang diperoleh melalui studi kepustakaan, studi dokumen, dan wawancara.

${ }^{7}$ Eko Riyadi dan Supriyanto Abdi (ed.), Mengurai Kompleksitas Hak Asasi Manusia (Kajian Multi Perspektif), Pusham-UII, Yogyakarta, 2007, hlm. 246. 


\section{Hasil Penelitian dan Pembahasan}

\section{Pengaturan Perlindungan Hukum Korban Kekerasan Berbasis Gender Online di Indonesia}

Kekerasan Berbasis Gender Online (KBGO) secara istilah masih cukup baru meskipun sesungguhnya KBGO merupakan fenomena yang sangat dekat dengan kehidupan masyarakat yang saat ini tidak bisa lepas dari bayang-bayang teknologi internet. Sederhananya, segala perbuatan yang menyerang gender dan/atau seksualitas tertentu yang difasilitasi oleh teknologi internet adalah KBGO. Kitab Undang-Undang Hukum Pidana (KUHP) sendiri tidak mengenal definisi Kekerasan Berbasis Gender. KUHP baru mengatur perbuatan yang melanggar kesopanan/kesusilaan sebagai perbuatan cabul sebagaimana diatur dalam Pasal 289 KUHP. 8

Istilah perbuatan cabul tersebut diartikan sebagai perbuatan yang melanggar rasa kesusilaan, atau perbuatan lain yang keji, dan semuanya dalam lingkup nafsu birahi kelamin, misalnya cium-ciuman, meraba-raba anggota kemaluan, meraba buah dada dan sebagainya. ${ }^{9}$ Namun demikian, dalam rangka perlindungan terhadap korban, negara hanya mengaturnya dalam Pasal 285 $\mathrm{KUHP}^{10}$ tentang perkosaan yang hanya ditujukan apabila pelakunya adalah lakilaki dan tidak diberikan penjelasan khusus kepada perempuan yang menjadi korban. Pasal-pasal dalam KUHP yang masih terbatas pada perbuatan cabul dan perkosaan ini juga hanya mengatur pada perbuatan-perbuatan yang dilakukan secara langsung dan belum membahas lebih lanjut soal perbuatan yang tidak dilakukan secara langsung terkhusus perbuatan di internet.

Untuk mengakomodir perbuatan-perbuatan yang menyerang seksualitas dalam medium internet, instrumen yang digunakan adalah Undang-Undang Nomor 11 Tahun 2008 tentang Informasi dan Transaksi Elektronik (UU ITE) dan Undang-Undang Nomor 44 Tahun 2008 tentang Pornografi (UU Pornografi). UU Pornografi mengatur secara umum terkait pendistribusian konten pornografi sebagaimana diatur dalam Pasal 29 yang menyatakan bahwa dipidana dengan pidana penjara paling singkat 6 bulan dan paling lama 12 tahun dan/atau pidana denda paling sedikit Rp. 250.000.000,00 dan paling banyak Rp. 6.000.000.000,00 bagi setiap orang yang memproduksi, membuat, memperbanyak, menggandakan,

8 Pasal 289 KUHP berbunyi, "Barang siapa dengan kekerasan atau ancaman memaksa seseorang untuk melakukan atau membiarkan dilakukan perbuatan cabul, diancam karena melakukan perbuatan yang menyerang kehormatan kesusilaan dengan pidana penjara paling lama sembilan tahu."

${ }_{9}$ R. Soesilo, Kitab Undang-Undang Hukum Pidana (KUHP) Serta Komentar-Komentarnya Lengkap Pasal Demi Pasal, Politeia, Bogor, 1991, hlm. 212.

10 Pasal 285 KUHAP berbunyi, "berbunyi "Barang siapa dengan kekerasan atau ancaman kekerasan memaksa seseorang wanita bersetubuh dengan dia di luar perkawinan, diancam karena melakukan perkosaan dengan pidana penjara paling lama dua belas tahun." 
menyebarluaskan, menyiarkan, mengimpor, mengekspor, menawarkan, memperjualbelikan, menyewakan, atau menyediakan pornografi.

Pasal tersebut tidak menekankan kepada penyebarluasan dalam ranah online sehingga tidak ada kategorisasi khusus terkait ranah apa saja yang dapat digunakan untuk melakukan pendistribusian konten pornografi. Definisi pornografi sebagaimana Pasal 1 angka 1 UU Pornografi adalah gambar, sketsa, ilustrasi, foto, tulisan, suara, bunyi, gambar bergerak, animasi, kartun, percakapan, gerak tubuh, atau bentuk pesan lainnya melalui berbagai bentuk media komunikasi dan/atau pertunjukan di muka umum, yang memuat kecabulan atau eksploitasi seksual yang melanggar norma kesusilaan dalam masyarakat. Pasal 39 UU Pornografi mengatur bahwa perbuatan pornografi adalah sebuah kejahatan yang harus memenuhi unsur kesengajaan didalamnya. Sedangkan definisi secara lebih lanjut terkait bentuk-bentuk pornografi, misalnya eksploitasi seksual yang diatur dalam Pasal 1 angka 1 tidak dijelaskan secara komprehensif. Selain itu, UU Pornografi juga belum mengatur perlindungan korban mengingat masih terbatas kepada pemberian pemidanaan bagi pelaku.

Instrumen hukum lain yang digunakan dalam penyelesaian kasus perbuatan yang menyerang seksualitas di ranah online adalah Pasal 27 UU ITE yang mengatur ketentuan pidana bagi setiap orang dengan sengaja dan tanpa hak mendistribusikan dan/atau mentransmisikan dan/atau membuat dapat diaksesnya informasi elektronik dan/atau dokumen elektronik yang memiliki muatan yang melanggar kesusilaan. Akan tetapi, definisi kesusilaan sebagaimana yang dimaksud dalam pasal tersebut juga tidak ada penjelasan secara lebih lanjut sehingga belum tepat apabila kasus-kasus KBGO diselesaikan dengan UU ITE. Jadi, UU ITE juga belum secara lebih lanjut mengatur soal mekanisme perlindungan terhadap korban.

Kedua undang-undang tersebut adalah regulasi yang paling sering digunakan dalam penyelesaian kasus-kasus KBGO. Kasus KBGO yang sampai saat ini berhasil diselesaikan sampai di tahap putusan pengadilan adalah kasus revenge porn atau pornografi balas dendam yang juga merupakan kasus dengan pelaporan tertinggi sebagai kategori KBGO kepada komnas perempuan. Namun sayangnya, kasus revenge porn dalam dua putusan yang berbeda juga diputus dengan penggunaan pasal yang berbeda, yang menunjukkan adanya inkonsistensi dalam penerapan hukum bagi kasus-kasus KBGO.

Dua putusan terkait kasus revenge porn tersebut yaitu Putusan Pengadilan Nomor 645/PID.B/2015/PN Mlg dan Nomor 6/Pid.Sus/2018/PN SMN yang pada dasarnya mengadili perkara yang sama, yaitu sama-sama penyebarluasan konten seksual akibat berakhirnya hubungan antara korban dan pelaku, namun 
diputus dengan dua hukum yang berbeda, dimana salah satunya menggunakan UU Pornografi dan UU ITE. Lembaga Bantuan Hukum Jakarta (LBH Jakarta) selaku salah satu lembaga yang menangani kasus KBGO berupa revenge porn menjelaskan bahwa baik UU ITE maupun UU Pornografi tidak sejalan dengan semangat perlindungan korban KBGO mengingat keduanya tidak secara spesifik mengatur perlindungan korban KBGO. ${ }^{11}$ LBH Jakarta juga menyatakan bahwa terdapat pasal-pasal yang kurang tepat seperti Pasal 27 ayat (3) UU ITE yang justru sering digunakan untuk mengkriminalisasi masyarakat pada umumnya. ${ }^{12}$

Penggunaan UU ITE dan UU Pornografi sebagai upaya penyelesaian kasus KBGO tersebut justru membuka celah untuk bisa mengkriminalisasi masyarakat. Salah satu kasus akibat dari kriminalisasi UU ITE adalah kasus dari Baiq Nuril. ${ }^{13}$ Upaya perlindungan diri Baiq Nuril dari perbuatan atasannya yang melakukan pelecehan seksual secara verbal terhadapnya justru membawa Baiq Nuril didakwa telah melanggar Pasal 27 ayat (1) UU ITE juncto Pasal 45 UU ITE oleh Jaksa Penuntut Umum pada Kejaksaan Negeri Mataram. Pada 26 Juli 2017, walaupun Baiq Nuril dinyatakan bebas oleh Pengadilan Negeri Mataram dan tidak terbukti melanggar Pasal 27 ayat (1) UU ITE, Jaksa Penuntut Umum Kejaksaan Negeri Mataram kemudian justru mengajukan kasasi ke Mahkamah Agung pada 1 Agustus 2018 dan kemudian Mahkamah Agung memutuskan Baiq Nuril bersalah telah melanggar pasal tersebut.

Baiq Nuril sudah berupaya untuk melakukan upaya balik dengan melaporkan pelaku dengan Pasal 294 ayat (2) butir 1 KUHP tentang Perbuatan Cabul dalam Sebuah Relasi Kerja yang laporan tersebut teregistrasi dengan nomor LP/334/XI/2018/NTB/SPKT. Namun pada 28 Januari 2019, laporan tersebut diberhentikan oleh Polda Nusa Tenggara Barat karena dianggap tidak memiliki cukup bukti dan tidak ada kontak fisik yang terjadi. Pada akhirnya Baiq Nuril mendapatkan amnesti dari Presiden Joko Widodo yang juga telah disetujui oleh Komisi III DPR RI setelah sebelumnya juga upaya Peninjauan Kembali atas kekhilafan hakim MA yang diajukannya juga ditolak.

Kasus lain yang menunjukkan bahwa UU Pornografi juga membuka kemungkinan kriminalisasi kepada korban kekerasan seksual adalah Kasus PA, seorang anak perempuan yang berusia 16 tahun, yang sedang diadvokasi oleh Jaringan Solidaritas untuk Keadilan Perempuan yang saat ini sedang menggalang

11 Wawancara dengan Oky Wiratama, Pengacara Lembaga Bantuan Hukum Jakarta pada 2 Mei 2020

12 Ibid

${ }^{13}$ SafeNet Indonesia, Kasus Ibu Nuril, Artikel: https://id.safenet.or.id/2017/07/kasus-ibu-nuril/ diakses pada 26 Mei 2020 pada pukul 23.12 WIB. 
dukungan melalui situs change.org. ${ }^{14} \mathrm{PA}$ yang dinikahkan siri merupakan korban poligami 3 kali oleh suaminya. PA dalam pernikahannya mengalami kekerasan verbal dan seksual yang keji dari suaminya serta menjadi korban perdagangan manusia. Di dalam narasi tersebut dinyatakan bahwa PA dijual oleh suaminya dengan cara dipaksa melakukan hubungan seksual dengan 3 laki-laki termasuk suaminya dan suaminya tersebut memaksa untuk merekam adegan tersebut walaupun dengan penolakan PA. Dalih suami PA adalah untuk koleksi pribadi, namun video tersebut malah tersebar dan menjadi viral. PA kemudian juga diputus bersalah bersama suaminya karena terbukti melanggar Pasal 4 ayat (1) UU Pornografi dengan menjatuhkan pidana 3 tahun penjara dan Rp. 1.000.000.000,00 subsidair 3 bulan penjara.

PA dinyatakan bersalah karena secara sah turut serta dalam obyek yang mengandung pornografi dan sebagai 'pemeran utama dalam video tersebut. Di dalam UU Pornografi diatur bahwa segala bentuk tindak pidana pornografi adalah tindak pidana yang sengaja (dolus). ${ }^{15}$ Sedangkan secara redaksi, UU Pornografi masih janggal dalam menentukan tindak pidana pornografi. Unsur sengaja dalam UU Pornogradi disebutkan dengan kalimat 'dengan sengaja"'yang merupakan unsur subyektif yang selanjutnya menimbulkan konsekuensi dalam penentuan pelaku tindak pidana pornografi sehingga Jaksa Penuntut Umum wajib membuktikan bahwa perilaku tersebut memenuhi unsur 'dengan sengaja' atau doluslopezt.

PA sebagai korban pernikahan dini, poligami, KDRT, perdagangan manusia serta KBGO, berdasarkan hasil konseling, diketahui mengalami dampak psikis dan trauma. Namun, dalam putusan majelis hakim di atas hanya berfokus kepada viralnya gambar dan video pornografi PA tanpa melihat bahwa PA adalah korban. PA menjadi korban KBGO yang dilakukan karena selain dalam pembuatan video tersebut tidak dalam konsensus yang diberikan oleh PA dan PA juga berada dalam kondisi terhalang relasi kuasa atas suaminya. Terkait hal ini, distribusi video intim tanpa konsensual merupakan KBGO. Di sisi lain, framing yang dilakukan dalam pemberitaan terkait kasus ini masih cukup seksis dan tidak berprespektif kepada korban, seperti judul berita yang diberitakan oleh merdeka.com yaitu 'Pemeran Perempuan di Video Vina Garut Divonis Tiga Tahun

\footnotetext{
14 Jaringan Solidaritas Untuk Keadilan Perempuan, Keadilan Untuk PA "Jangan penjarakan PA!" Artikel: https://www.change.org/p/ketua-pengadilan-tinggi-garut-pa-korban-eksploitasi-harusnya-dilindungi-bukandipidana-janganpenjarakanpa diakses pada tanggal 27 Mei 2020 pada pukul 0.48 WIB.

${ }^{15}$ Dadin Eka Saputra, "Kajian Yuridis terhadap Tindak Pidana Pornografi Melalui Media Sosial”, $A l$ 'Adl, Volume IX Nomor 2, Agustus 2017 ISSN 1979-4940/ISSN-E 2477-0124
} 
Penjara'.16 Pemberitaan lain yang justru mengulik kehidupan pribadi korban adalah pemberitaan yang diberitakan oleh situs Bombastis.com dimana situs berita tersebut menggunakan judul 'Fakta Pedih Vina Garut, Demi Duit dan Turuti Keinginan Menyimpang Suami tapi Malah Dibui'17 justru juga membuat PA kembali menjadi korban KBGO berupa doxing atau penyebaran informasi personal sensitif yang dapat menimbulkan reviktimisasi berulang dari masyarakat yang cenderung masih menganggap bahwa perempuan korban kekerasan seksual adalah aib. Kondisi patriarkis dalam masyarakat, framing media yang tidak terikat kode etik, tekanan ekonomi, hingga minimnya pemahaman terkait seksualitas, kekerasan berbasis gender dan edukasi terkait penggunaan internet yang sehat adalah faktorfaktor pendorong KBGO semakin meningkat di Indonesia.

Mahkamah Agung telah menerbitkan aturan yang sangat condong kepada pemenuhan nilai-nilai keadilan gender melalui Peraturan Mahkamah Agung Nomor 3 Tahun 2017 tentang Pedoman Mengadili Perkara Perempuan Berhadapan dengan Hukum. Namun, dalam praktek penyelesaian kasus yang berkaitan dengan seksualitas, majelis hakim pemeriksa perkara masih belum memperhatikan bagaimana status sosial para pihak yang berperkara, apakah para pihak setara dalam kondisi status sosial ataupun terdapat ketimpangan antara satu sama lain. Selain itu, Majelis hakim selaku pemutus perkara juga perlu untuk memperhatikan perlindungan hukum yang didapatkan kepada para pihak, terkhusus terkait akses keadilan, dampak psikis, assessment psikologis, dampak fisik hingga faktor diskriminasi yang dialami para korban. Para pihak mungkin saja dalam keadaan fisik yang tidak berdaya, relasi kuasa yang timpang dan traumatis yang berlebih sehingga mengakibatkan saksi/korban tidak berdaya dan tidak mampu menjelaskan bagaimana keadaan yang terjadi.

Pemaparan di atas menunjukkan bahwa implementasi peraturan terkait KBGO di Indonesia masih inkonsisten dan minimnya pemahaman yang menyeluruh mengenai gender dan seksualitas terlebih kepada para penegak hukum baik kepolisian, kejaksaan, keseluruhan tingkat pengadilan dan terkhusus para pendamping hukum maka sekiranya perlu adanya suatu peraturan terkhusus yang membahas lebih lanjut mengenai penyelesaian kasus kekerasan berbasis gender baik di ranah online maupun offline yang tidak melupakan konsep perlindungan terhadap korban.

16 Merdeka.com, Pemeran Perempuan di Video Vina Garut Divonis Tiga Tabun Penjara, Artikel: https://www.merdeka.com/peristiwa/pemeran-perempuan-di-video-vina-garut-divonis-tiga-tahun-penjara.html diakses pada tanggal 27 Mei 2020 pada pukul 1.12 WIB.

17 Anonim, Fakta Pedih Vina Garut, Demi Duit dan Turuti Keinginan Menyimpang Suami tapi Malah Dibui Artikel: https://www.boombastis.com/fakta-vina-garut/247473 diakses pada 27 Mei 2020 pada pukul 1.20 WIB. 


\section{Konstruksi Hukum Perlindungan Korban Kekerasan Berbasis Gender Online menurut Hukum Hak Asasi Manusia}

Resolusi Dewan HAM Perlindungan Bangsa-Bangsa (PBB) tentang Perlindungan dan Penegakan Hak Asasi Manusia di Internet menegaskan bahwa hak-hak manusia yang dilindungi di ranah offline juga harus dilindungi ketika berada di ranah online. ${ }^{18}$ Selain itu, Agenda PBB 2030 tentang tentang Pembangunan Berkelanjutan (Substainable Development Goals) ke-6 tentang kesetaraan gender menyatakan bahwa penggunaan teknologi terkhusus teknologi informasi dan komunikasi harus digunakan untuk mempromosikan pemberdayaan perempuan dan penghapusan segala bentuk kekerasan terhadap perempuan dan anak perempuan di ruang publik maupun privat, termasuk perdagangan manusia dan eksploitasi seksual dan jenis lainnya.

Negara-negara lain di lingkup wilayah Uni Eropa secara lebih lanjut telah mendefinisikan dan memberikan perlindungan khusus bagi kejahatan terhadap perempuan di internet, misalnya Konverensi Budapest tentang Cybercrime yang merupakan pernjanjian internasional pertama yang berfokus pada kejahatan di internet yang dalam Pasal 9 dan sub ketentuannya membahas soal gambar eksploitasi tentang anak yang menghasilkan pornografi untuk distribusi elektronik dan produksi anak yang menyebabkan kematian dan kekerasan fisik dan/atau psikologis. Lebih lanjut Uni Eropa menambahkan kebutuhan atas KBGO dalam instrumen-instrumen yang akan melindungi perempuan dan anak perempuan dari jenis kekerasan ini, yaitu Petunjuk Hak Korban, Petunjuk tentang Pencegahan dan Pemberantasan Perdagangan Manusia dan Upaya Melindungi Korban, Petunjuk untuk Memerangi Eksploitasi Seksual Anak-Anak secara Online dan Pornografi Anak, dan Petunjuk Hak Korban. ${ }^{19}$

Di Indonesia, ketentuan terkait perlindungan hukum korban KBGO termuat dalam Rancangan Undang-Undang Penghapusan Kekerasan Seksual (RUU PKS) dimana pembahasannya tertunda sejak permulaan pembahasan prolegnas pada awal 2015.20 RUU PKS mengatur tindak pidana kekerasan seksual yang tidak seluruhnya diatur dalam Kitab Undang-Undang Hukum Pidana (KUHP) sehingga RUU PKS dapat dikatakan sebagai lex specialist (ketentuan khusus) dari KUHP. RUU PKS mengatur 9 bentuk kekerasan seksual yang pada dasarnya

18 Dewan Hak Asasi Manusia Sesi ke tiga puluh Agenda nomor 3, Resolusi yang diadopsi oleb Dewan Hak Asasi Manusia pada 1 Juli 2016, Artikel : http://ap.ohchr.org/documents/dpage_e.aspx?si=A/HRC/RES/32/13 diakses pada 4 Mei 2020, pada pukul 3.10 WIB.

${ }^{19}$ European Parliament and the Council, Directive 2012/29/EU of the European Parliament and of the Council of 25 October 2012 establishing minimum standards on the rights, support and protection of victims of crime, and replacing Council Framework Decision 2001/220/JHA, 2012, Artikel: https://eur-lex.europa.eu/legalcontent/en/TXT/?uri=CELEX\%3A32012L0029 diakses pada 7 Mei 2020 pada pukul 17.08 WIB.

${ }^{20}$ Nur Janti, Artikel: https://historia.id/politik/articles/menanti-ruu-pks-disahkan-Dpw1n diakses pada tanggal 9 Mei 2020 pada pukul 2.15 WIB. 
dapat juga diberlakukan pada kasus KBGO. Akan tetapi, rumusan RUU PKS tersebut masih perlu diperbaiki agar dapat memenuhi perlindungan hukum korban KBGO.

Konstruksi perlindungan hukum korban KBGO tersebut yaitu dengan menambah dan melakukan perubahan klausa pada RUU PKS sehingga RUU PKS dapat diberlakukan secara lebih komprehensif dalam melindungi hak-hak korban KBGO. Misalnya yaitu perluasan definisi 'secara tidak langsung' yang dirujukkan kepada perbuatan-perbuatan yang dilakukan di internet sehingga menjadikan definisi-definisi Kekerasan Seksual dalam RUU PKS yang sudah ada sebelumnya dapat juga diterapkan kepada korban-korban KBGO yang motif dan bentuk kekerasannya sejenis. Selain itu, perlu dilakukan penambahan peraturan mengenai pemulihan data digital korban yang sebelumnya tidak diatur dalam RUU PKS. Pemulihan data digital merupakan salah satu aspek yang cukup penting untuk diberikan kepada korban-korban KBGO. Selain karena kekerasan yang dilakukan terdapat dalam medium digital, perlindungan data digital dapat dijadikan sebagai upaya sekaligus untuk memperbaiki citra serta nama baik korban-korban KBGO secara digital.

Perlunya pengaturan terkait proses penjalinan kerjasama antara UPT dengan Badan Siber dan Sandi Negara (BSSN) sebagai upaya taktis dalam percepatan pencarian pelaku yang berada di ranah online. Selain karena tidak semua unit kepolisian memiliki Cyber Crime Investigation Center (CCIC), kerjasama dengan BSSN adalah sebuah upaya yang dapat dilakukan untuk meminimalisir bentuk-bentuk lain yang dilakukan pelaku serta upaya yang bisa dilakukan untuk melacak modus-modus KBGO yang berpotensi dilakukan lintas negara. Selain itu, pentingnya menambahkan pengaturan mengenai pelaporan online. Hal tersebut dimaksudkan sebagai upaya yang dapat dilakukan secara cepat ketika korban mengetahui bahwa sedang dalam kondisi dilakukan KBGO oleh orang lain sehingga pelaporan online dapat memangkas waktu yang digunakan korban untuk mendatangi langsung pihak kepolisian atau UPT. Hal tersebut juga akan dibarengi dengan percepatan pendistribusian konten KBGO yang dilakukan karena medium internet sangat cepat dan tidak terbatas ruang dan waktu.

Tidak semua korban sepakat ketika penyelesaian kasusnya dibawa ke ranah hukum, hingga sampai ke litigasi. Oleh sebab itu, selain konstruksi perlindungan hukum di atas, perlu juga diatur mekanisme penanganan dan perlindungan korban secara sosial. Bentuknya dapat berupa upaya masyarakat atau teman sekitar dalam pembentukan support group (suatu metode terapi antar kelompok yang memiliki permasalahan/pengalaman yang serupa) atau peer group (teman sebaya) untuk dapat menjadi pendengar yang baik, yang dapat mendengarkan 
tanpa memberikan justifikasi di awal, mencatat pengalaman-pengalaman yang dialami korban, yang selanjutnya catatan tersebut merupakan rujukan korban untuk melakukan proses lain yang lebih lanjut. Sikap untuk tidak menanyakan kepada korban terkait kronologi, bentuk-bentuk victim blaming adalah sikap-sikap yang harus dihindari dalam upaya sebagai support/peer group. Support/peer group ini juga dapat digunakan sebagai langkah awal sebelum korban menyiapkan mental dalam penyelesaian kasus di ranah hukum.

Proses penanganan kasus kekerasan seksual baik yang bersifat langsung maupun online memerlukan mekanisme hukum acara yang sedikit berbeda dari penanganan kasus pidana biasa. Oleh karena itu, konstruksi perlindungan korban KBGO juga perlu mengatur prosedur khusus terkait pemeriksaan di pengadilan. Misalnya, dalam persidangan di pengadilan sebaiknya tidak ada pertemuan langsung dalam satu tempat dan waktu yang sama antara korban dan pelaku, karena hal tersebut memungkinkan akan timbulnya trauma yang dapat dialami kepada para korban yang diberikan kesempatan untuk bertatap muka secara langsung kepada para pelaku yang telah mencemarkan harga diri, martabat dan seksualitasnya. Selain itu, data-data dan identitas diri korban tidak perlu ditampilkan pada saat persidangan maupun dalam putusan, karena pada dasarnya penyelesaian masalah kekerasan seksual tidak bisa serta merta disamakan dengan penyelesaian kasus hukum terkhusus pidana biasa. Para korban perlu untuk dilindungi identitasnya, karena hal tersebut mencakup harga diri dan martabat korban yang akan kembali tercoreng dan tercemar di samping tindakan KBGO yang telah dialaminya.

Perlindungan korban KBGO juga meliputi upaya memperbaiki struktur hukum, yaitu apparat penegak hukum. Penyebarluasan informasi terkait KBGO yang merupakan sebuah kekerasan yang dampaknya bisa sama atau lebih parah daripada kekerasan seksual biasa yang juga harus dipahami sebagai sebuah fenomena yang penting untuk segera ditangani. Masih banyak aparat hukum terkhusus kepolisian sebagai lembaga negara yang berwenang saat ini untuk menyampaikan laporan terkait kasus kejahatan masih belum mempunyai prespektif kepada korban. ${ }^{21}$ Di sisi lain, pendidikan dan pelatihan khusus perlu diberikan kepada para penegak hukum terkhusus kepolisian tentang penanganan kasus agar dapat berprespektif korban, sehingga nantinya dalam penanganan segala bentuk kekerasan seksual baik online maupun offline dapat memenuhi keadilan bagi para korban. Karena hingga saat ini, masih banyak korban KBGO yang dalam pelaporan nya masih sulit dilayani karena kekurangan alat bukti

21 Wawancara dengan Ellen Kusuma, Kepala Sub Divisi KBGO Southeast Asia Freedom of Expression Network/SAFEnet, 24 April 2020. 
yang membuat sangat banyak kasus-kasus KBGO yang tidak dapat diselesaikan secara hukum. ${ }^{22}$

\section{Penutup}

Indonesia belum memiliki peraturan perundang-undangan yang secara khusus mengatur perlindungan hukum korban Kekerasan Berbasis Gender Online (KBGO) sehingga penanganan kasus terkait KBGO masih berdasar pada UndangUndang Nomor 11 Tahun 2008 tentang Informasi dan Transaksi Elektronik (UU ITE) dan Undang-Undang Nomor 44 Tahun 2008 tentang Pornografi (UU Pornografi). Akan tetapi, pada praktek penegakan hukum KBGO, penerapan kedua undang-undang tersebut masih inkonsisten. Selain itu, UU ITE dan UU Pornografi masih berfokus kepada penyelesaian kasus dengan memberikan hukuman pada para pelaku dan mengabaikan konsep perlindungan terhadap korban yang justru sangat dibutuhkan.

Ketentuan perlindungan hukum korban KBGO termuat dalam Rancangan Undang-Undang Penghapusan Kekerasan Seksual (RUU PKS). Akan tetapi, rumusan RUU PKS tersebut masih perlu direvisi agar dapat memenuhi perlindungan hukum korban KBGO. Konstruksi hukum perlindungan korban KBGO tersebut yaitu dengan menambah dan melakukan perubahan klausa pada RUU PKS sehingga RUU PKS dapat diberlakukan secara lebih komprehensif dalam melindungi hak-hak korban KBGO. Misalnya yaitu perluasan definisi 'secara tidak langsung', penambahan peraturan mengenai pemulihan data digital korban, pengaturan terkait proses penjalinan kerjasama antara UPT dengan Badan Siber dan Sandi Negara (BSSN), menambahkan pengaturan mengenai pelaporan online, ketentuan terkait mekanisme penanganan dan perlindungan korban secara sosial, prosedur khusus terkait hukum acaranya, dan memperbaiki struktur hukum (aparat penegak hukum).

\section{Daftar Pustaka}

\section{Buku}

Atmosudirjo, Prajudi, Hukum Administrasi Negara, Ghalia Indonesia, Jakarta, 1994.

Fakih, Mansour, Analisis Gender dan Transformasi Sosial, Pustaka Pelajar, Yogyakarta, 1996.

HR, Ridwan, Hukum Administrasi Negara, Raja Grafindo Persada, Jakarta, 2011.

Mahmud Marzuki, Peter, Pengantar Ilmu Hukum (Edisi Revisi), Kencana Prenanda Media Group, Jakarta, 2013.

22 Wawancara dengan Oky Wiratama, Pengacara Lembaga Bantuan Hukum Jakarta pada 2 Mei 2020. 
Rahardjo, Budi, Memahami Teknologi Informasi, Elexmedia Komputindo, Jakarta, 2002.

Riyadi, Eko, dan Supriyanto Abdi (ed.), Mengurai Kompleksitas Hak Asasi Manusia (Kajian Multi Perspektif), Pusham-UII, Yogyakarta, 2007.

Soesilo, R., Kitab Undang-Undang Hukum Pidana (KUHP) Serta KomentarKomentarnya Lengkap Pasal Demi Pasal, Politeia, Bogor, 1991.

Sudiarti Luhulima, Achie, CEDAW Menegakkan Hak Asasi Perempuan, Yayasan Pustaka Obor, Jakarta, 2014.

Stahl, Julius dalam Jimly Asshiddiqie, Konstitusi \& Konstitualisme Indonesia, Cet. 2. Sinar Grafika, Jakarta, 2011.

\section{Jurnal}

CEDAW, "General Recommendation No. 19" (11th session, 1992), Artikel: http:/ / www.un.org/womenwatch/daw/cedaw/recommendations/inde x.html, 1992

Dadin Eka Saputra, "Kajian Yuridis terhadap Tindak Pidana Pornografi Melalui Media Sosial", Al'Adl, Volume IX Nomor 2, Agustus 2017 ISSN 19794940/ISSN-E 2477-0124

Dewan Hak Asasi Manusia Sesi ke tiga puluh Agenda nomor 3, Resolusi yang diadopsi oleh Dewan Hak Asasi Manusia pada 1 Juli 2016, Artikel: http://ap.ohchr.org/documents/dpage_e.aspx?si=A/HRC/RES/32/13

Enju Juanda, "Konstruksi Hukum dan Metode Intepretasi Hukum", Universitas Galuh, Jurnal Ilmiah Galuh Justisi, Volume: 4 No. 2 September 2016.

European Parliament and the Council, Directive 2011/36/eu of the European Parliament and of the Council of 5 april 2011 on preventing and combating trafficking in human beings and protecting its victims, and replacing Council Framework Decision 2002/629/jha, 2011 Artikel: https://eurlex.europa.eu/LexUriServ/LexUriServ.do?uri=OJ:L:2011:101:0001:0011:E $\mathrm{N}: \mathrm{PDF}$

European Parliament and the Council, Directive 2011/92/EU of the European Parliament and of the Council of 13 December 2011 on combating the sexual abuse and sexual exploitation of children and child pornography, and replacing Council Framework Decision 2004/68/JHA, 2011, Artikel: https://eurlex.europa.eu/legal-content/EN/TXT/?uri=celex\%3A32011L0093

European Parliament and the Council, Directive 2012/29/EU of the European Parliament and of the Council of 25 October 2012 establishing minimum standards on the rights, support and protection of victims of crime, and replacing Council Framework Decision 2001/220/JHA, 2016, Artikel: https://eurlex.europa.eu/legal-content/en/TXT/?uri=CELEX\%3A32012L0029.

European Parliament and the Council, Directive 2012/29/EU of the European Parliament and of the Council of 25 October 2012 establishing minimum standards on the rights, support and protection of victims of crime, and replacing Council Framework Decision 2001/220/JHA, 2012, Artikel: https://eurlex.europa.eu/legal-content/en/TXT/?uri=CELEX\%3A32012L0029 
Jaringan Solidaritas Untuk Keadilan Perempuan, Keadilan Untuk PA "Jangan penjarakan PA!" Artikel: https://www.change.org/p/ketua-pengadilantinggi-garut-pa-korban-eksploitasi-harusnya-dilindungi-bukan-dipidanajanganpenjarakanpa.

Shigenori Matsuri, "The Criminalization of Revenge Porn in Japan”, Washington International Law Journal Association, Vol. 24 No. 22015.

Sida, "Preventing and Responding to Gender-Based Violence: Expressions and Strategies", Art.no.: SIDA61848en, 2015, hlm. 6. Artikel https: / / www.sida.se/contentassets/3a820dbd152f4fca98bacde8a8101e15 /preventing-and-responding-to-gender-based-violence.pdf.

\section{Website}

Anonim,, Fakta Pedih Vina Garut, Demi Duit dan Turuti Keinginan Menyimpang Suami tapi Malah Dibui Artikel: https:/ / www.boombastis.com/fakta-vinagarut/247473 diakses pada 27 Mei 2020 pada pukul 1.20 WIB.

Catatan Tahunan Komnas Perempuan Tahun 2020

Merdeka.com, Pemeran Perempuan di Video Vina Garut Divonis Tiga Tahun Penjara, Artikel: https://www.merdeka.com/peristiwa/pemeran-perempuan-divideo-vina-garut-divonis-tiga-tahun-penjara.html diakses pada 27 Mei 2020 pada pukul 1.12 WIB.

Nur Janti, Artikel: https://historia.id/politik/articles/menanti-ruu-pksdisahkan-Dpw1n diakses pada 9 Mei 2020 pada pukul 2.15 WIB.

SafeNet Indonesia, Kasus Ibu Nuril, Artikel: https://id.safenet.or.id/2017/07/ kasus-ibu-nuril/ diakses pada 26 Mei 2020 pada pukul 23.12 WIB. 